\title{
EVALUASI MUTU FISIK DAN NILAI GIZI PARBOILING RICE VARIETAS CISOKAN SUMATERA BARAT
}

\author{
Renny Eka Putri*, Ifmalinda, dan Nindi Elisa \\ Jurusan Teknik Pertanian dan Biosistem, Fakultas Teknologi Pertanian \\ Universitas Andalas \\ Limau Manis, Padang, Sumatera Barat 25163 \\ *rennyekaputri@ae.unand.ac.id
}

\begin{abstract}
Abstrak
Parboiled rice atau yang dikenal dengan beras pratanak adalah pengolahan gabah yang bertujuan untuk menaikkan persentase rendemen giling dan menurunkan persentase kadar glukosa sehingga dapat dikonsumsi oleh penderita diabetes melitus dan obesitas. Parboiled rice ini untuk mendapatkannya harus melakukan proses perendaman dan pengukusan dari gabah kemudian dikeringkan dan digiling. Penelitian ini bertujuan untuk menganalisa mutu fisik dan mutu gizi gabah varietas cisokan secara pratanak. Mutu fisik yang dievaluasi meliputi ukuran, bentuk, bulk density, kadar air, dan rendemen, sedangkan nilai gizi meliputu kadar gulosa dan kandungan pati. Hasil penelitian menunjukkan peningkatan rendemen giling pada perlakuan setelah dikukus 30 menit yaitu 79,965\% dibandingkan beras tanpa proses pratanak. Proses pratanak juga dapat menurunkan kadar glukosa pada beras 0,529\% dan menaikkan kadar pati menjadi 78,614\%.
\end{abstract}

Kata Kunci : Parboiled rice, Cisokan, Mutu Fisik, Glukosa, Rendemen

Submit : 9 Maret $2021 *$ Revisi : 12 April $2021 *$ Accepted : 16 April $2021 *$ Publish : 10 Mei 2021 


\section{PENDAHULUAN}

Peningkatan produksi beras di Indonesia terus mengalami kenaikan, namun peningkatan tersebut belum mampu memenuhi konsumsi beras di Indonesia. Tingginya konsumsi beras dapat berdampak buruk bagi kesehatan terutama penyakit diabetes dan obesitas karena kebiasaan orang Indonesia yang lebih menyukai nasi yang pulen dengan kandungan amilosa yang rendah yaitu 20\% (Hasbullah dan Surahman, 2015). Berdasarkan Riset Kesehatan Nasional (Rikernas) tahun 2016, penduduk berusia diatas 18 tahun mengalami obesitas sebesar 20,7\%. Nilai ini lebih tinggi dibanding pada tahun 2013 yaitu 15,4\%.

Indeks glikemik merupakan tingkatan pangan menurut efeknya terhadap kadar glukosa darah. Pangan yang tergolong ke dalam nilai indeks glikemik yang tinggi apabila dapat menaikkan kadar gula dengan rentang waktu yang relatif cepat dan pangan yang tergolong ke dalam nilai indeks glikemik yang rendah apabila dapat menaikkan kadar glukosa dengan rentang waktu yang cukup lama menurut Rimbawa dan Siagian (2004). Beras pratanak merupakan gabah yang mengalami proses pengolahan beberapa tahapan yaitu perendaman, pengukusan, pengeringan dan penggilingan. Perendaman bertujuan untuk mengalirkan air dari sel-sel pati endosperm ke dalam ruang intercellular yang akan diserap oleh sel-sel pati. Proses pengukusan dilakukan agar sel pati pada endosperm menjadi lunak dan terjadinya proses gelatinisasi (Fadhallah, 2016).

Widowati (2009) dan Fadhallah (2016) melakukan penelitian mengenai pengaruh lama pengukusan terhadap mutu fisik beras pratanak pada beberapa varietas gabah. Berdasarkan penelitian yang dilakukan Widowati (2009) nilai indeks glikemik pada beras pratanak dapat diturunkan dari indeks glikemik beras biasa yaitu 54,43-97,29\% menjadi 44,22-76,32\%.

Sumatera Barat yang mayoritas petani memiliki beberapa jenis varietas padi, namun jenis varietas padi yang terkenal adalah varietas cisokan. Padi jenis ini sangat terkenal karena menghasilkan nasi yang lembut dan tidak lengket ketika dimasak. Selain itu, nasi yang dihasilkan juga sangat enak dibandingkan dengan varietas padi lainnya. Permintaan yang banyak ini membuat para petani padi di Solok lebih banyak menanam padi dengan varietas tersebut.

\section{METODOLOGI PENELITIAN}

\section{Alat dan Bahan}

Bahan yang digunakan yaitu gabah dengan varietas cisokan dan untuk perendaman digunakan air bersih. Peralatan yang digunakan yaitu waterbath, timbangan digital, baki penampung, panci pengukus, thermometer, peniris, baki penampung, kompor, dan peralatan lainnya.

\section{Metode Penelitian}

Metode penelitian yang digunakan yaitu metode eksperimen. Menurut Spetriani (2011) metode dilakukan dengan membersihkan gabah dan direndam dengan air bersuhu $60^{\circ} \mathrm{C}$ hingga mendapatkan kadar air bahan hingga $30 \%$. Kemudian gabah tersebut dibagi ke dalam dua bagian dan diberi perlakuan panas dengan suhu $80 \pm 5^{\circ} \mathrm{C}$ dengan lama waktu yang berbeda yaitu 20 menit dan 30 menit. Selain itu juga dilakukan perbandingan dengan beras yang tanpa melalui proses parboiled 
yang kemudian dijadikan dengan sampel untuk kontrol, dalam setiap perlakuan dilakukan tiga kali ulangan. Setelah itu dilakukan proses pengeringan hingga mencapai kadar air 14\% kemudian dilakukan penggilingan dan pengamatan mutu fisik beras.

\section{Sifat Fisik Beas Pratanak}

Pengamatan sifat fisik pada beras ini dilakukan pada tiga kondisi yang meliputi gabah sebelum dilakukan proses pratanak, gabah setelah dikukus, dan gabah setelah dikeringkan hingga mencapai kadar air 14\%. Adapun parameter-parameter yang digunakan dibawah ini.

\section{Ukuran}

Ukuran gabah dan beras dilakukan dengan cara mengukur panjang, lebar dan tebal menggunakan jangka sorong sebanyak 100 sampel gabah. Pengukuran dilakukan sebelum dan sesudah gabah melalui tahapan parboiled. Sehingga akan diperoleh nilai Geometric Mean Diameter (GMD) gabah dengan rumus sebagai berikut :

$\mathrm{GMD}=(\mathrm{LxWxT})^{1 / 3}$

dengan:

$$
\begin{aligned}
\text { GMD } & =\text { Geometric Mean Diameter } \\
\mathrm{L} & =\text { Legth }(\mathrm{cm}) \\
\mathrm{W} & =\text { Width }(\mathrm{cm}) \\
\mathrm{T} & =\text { Thickness }(\mathrm{cm})
\end{aligned}
$$

\section{Bentuk}

Bentuk gabah dan beras ditentukan dengan mencari nilai sphericity. Jika nilai sphericity yang didapat bernilai 1 atau mendekati 1 maka biji dapat dikelompokkan dalam bentuk bulat. Pengukuran pada gabah ini dilakukan sebelum dan sesudah melalui tahapan parboiled. Sphericity dapat dihitung dengan persamaan sebagai berikut:
Sphericity $=\frac{\text { GMD }}{\mathrm{L}}$

dengan :

GMD = Geometric Mean Diameter

$\mathrm{L} \quad=\operatorname{Legth}(\mathrm{cm})$

\section{Bulk density}

Bulk density diukur dengan mengisi gabah dan beras sebelum melalui tahapan parboiled ke dalam gelas ukur $50 \mathrm{ml}$ yang kosong sehingga didapatkan volume gabah dan beras sebesar $50 \mathrm{ml}$, selanjutnya gabah dan beras diukur massanya dengan menggunakan timbangan digital. Setelah didapat volume dan massa gabah dan beras, maka nilai bulk density dapat dicari dengan persamaan berikut. Kemudian hal yang sama dilakukan pada gabah setelah melalui tahapan parboiled.

$\rho=\frac{M}{V}$

dengan :

$\rho \quad=$ Bulk density

$\mathrm{M} \quad=$ Massa $(\mathrm{g})$

$\mathrm{V}=$ Volume $\left(\mathrm{cm}^{3}\right)$

\section{Massa 1000 Biji}

Massa 1000 biji gabah dan beras dilakukan dengan menghitung hingga terkumpul sebanyak 1000 biji gabah dan beras untuk mendapatkan massanya ditimbang dengan menggunakan timbangan digital.

\section{Kadar Air, Metode Oven}

Pengukuran kadar air dilakukan pada kondisi yang meliputi gabah sebelum melalui tahapan pratanak, gabah setelah dikukus, dan gabah setelah dikeringkan hingga mencapai kadar air $14 \%$ yang ditentukan dengan metode oven. Kadar air dapat dihitung dengan menggunakan persamaan:

$\mathrm{M}=\frac{b-c}{b-a} \times 100 \%$

dengan: 


$$
\begin{aligned}
\mathrm{M}= & \text { Kadar air basis basah }(\%) \\
\mathrm{a}= & \text { berat cawan }(\mathrm{g}) \\
\mathrm{b}= & \text { berat cawan+sampel gabah } \\
& \text { sebelum dikeringkan }(\mathrm{g}) \\
\mathrm{c}= & \text { berat cawan }+ \text { sampel gabah } \\
& \text { setelah dikeringkan dengan } \\
& \text { oven pada suhu } 105^{\circ} \mathrm{C} \text { hingga } \\
& \text { berat konstan }(\mathrm{g})
\end{aligned}
$$

\section{Rendemen}

Nilai rendemen diperoleh dari perbandingan berat beras pratanak yang diperoleh dengan berat awal gabah yang akan digiling kemudian dihitung dengan rumus:

Rendemen $(\%)=\frac{b}{a} \times 100 \%$

dengan:

$\mathrm{b}=$ berat beras pratanak yang dihasilkan ( $\mathrm{g}$ )

$\mathrm{a}=$ berat awal gabah yang digunakan (g)

\section{Mutu Fisik (SNI 01-6128 : 2008)}

Sampel yang akan dilakukan pengamatan mutu fisik meliputi beras yang tidak diberi perlakuan, beras yang sudah dikukus selama 20 menit dan gabah yang sudah dikukus selama 30 menit. Setiap sampel yang akan diuji mutu fisik ditimbang sebanyak 100 gram dengan 3 kali ulangan menggunakan timbangan digital kemudian dilanjutkan dengan pemisahan secara visual menjadi beras kepala $(>2 / 3)$, beras patah $(1 / 3$ $2 / 3)$, dan beras menir $(<1 / 3)$.

\section{Uji Kadar Glukosa (Metode Luff- Schoorl)}

Pengamatan kadar glukosa juga dilakukan pada beras perlakuan setelah dikukus 20 menit, setelah dikukus 30 menit dan tanpa perlakuan. Metode yang digunakan yaitu metode Luff Schoorl.

\section{Kadar Pati dengan Metode Luff Schoorl}

Pengukuran kadar pati dilakukan pada beras perlakuan setelah dikukus 20 menit, setelah dikukus 30 menit dan tanpa perlakuan atau kontrol dengan metode Luff Schoorl.

\section{HASIL DAN PEMBAHASAN}

\section{Pengaruh Lama Pengukusan terhadap Sifat Fisik}

Pengaruh pengukusan terhadap beras pratanak atau parboiling rice dapat dilihat secara langsung dengan sifat fisik beras tersebut. Adapun sifat-sifat fisik yang menjadi parameter pengukuran yaitu GMD, sphericity, bulk density, dan massa 1000 biji gabah.

\section{Pengaruh Lama Pengukusan terhadap GMD}

Lama pengukusan pada gabah memberikan pengaruh terhadap GMD. Hubungan pengaruh pelakuan terhadap nilai GMD dapat dilihat pada Gambar 3. 


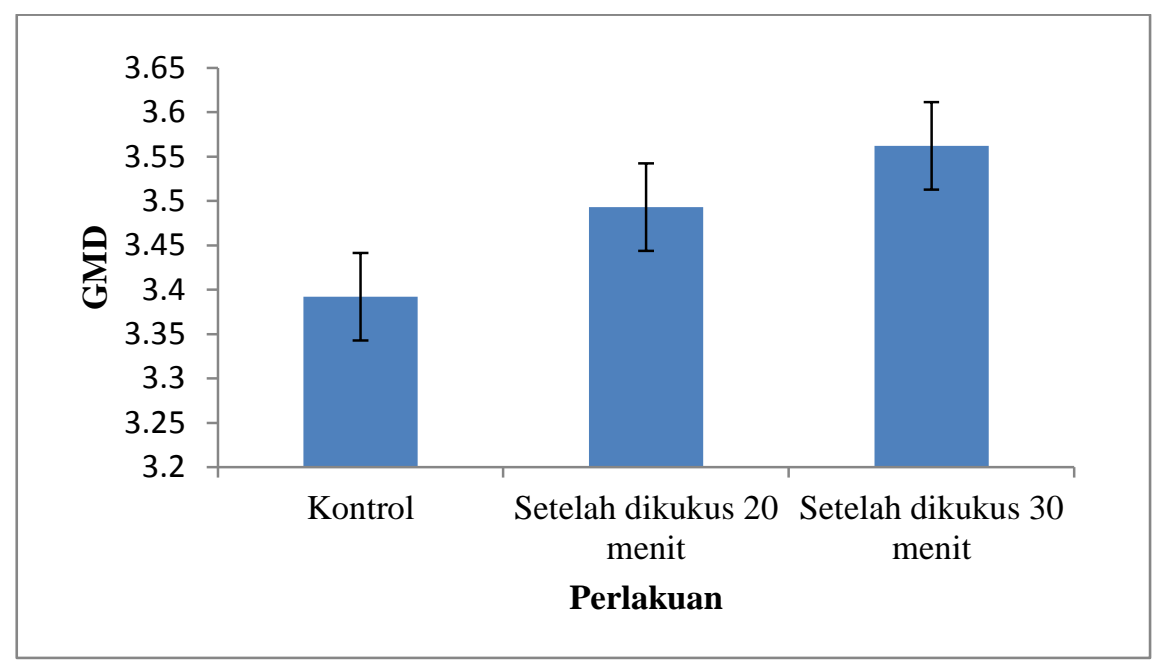

Gambar 3. Grafik Rata-rata GMD Gabah

Berdasarkan Gambar 3 terlihat grafik rata-rata GMD gabah disetiap perlakuan. Nilai GMD gabah terbesar yaitu 3,562 pada gabah setelah dikukus 30 menit dan nilai GMD terendah pada gabah tanpa perlakuan atau kontrol sebesar 3,392. Nilai GMD dipengaruhi berdasarkan bentuk fisik gabah karena nilai GMD diperoleh dari hasil pengukuran panjang, lebar dan tebal gabah. Jika ukuran panjang, lebar, dan ketebalan gabah besar, maka nilai GMD juga akan semakin besar dan sebaliknya. Selain itu, faktor yang mempengaruhi perbedaan GMD adalah kandungan air pada gabah. GMD gabah dengan perlakuan pengukusan 30 menit lebih besar dibandingkan dengan pengukusan selama 20 menit dan kontrol karena ketika perendaman dan pengukusan air masuk ke dalam lapisan endosperm gabah sehingga kadar air gabah menjadi lebih tinggi dan ukuran gabah menjadi lebih besar. Penelitian yang dilakukan oleh Zareiforoush et al., (2011) juga melakukan penelitian terhadap gabah varietas Hashemi dan memperoleh hasil adanya pengaruh yang cukup signifikan terhadap GMD gabah dengan kadar air. Analisa ANOVA GMD pada gabah dapat dilihat pada Tabel 1.

Tabel 1. Analisa ANOVA GMD Gabah

\begin{tabular}{cccccc}
\hline $\begin{array}{c}\text { Sumber } \\
\text { Keragaman }\end{array}$ & $\begin{array}{c}\text { Jumlah } \\
\text { Kuadrat }\end{array}$ & Derajat bebas & Kuadrat Tengah & F & Sig. \\
\hline Perlakuan & 1.449 & 2 & 0,725 & 44.647 & $1,1 \times 10-17$ \\
Galat & 4.819 & 297 & 0,016 & & \\
Total & 6.268 & 299 & & & \\
\hline Perlakun : Kontro, Seleloh dikukus 20 menit, Setelah dikuksu 30 menit & &
\end{tabular}

Perlakuan : Kontrol, Setelah dikukus 20 menit, Setelah dikuksu 30 menit

Analisa nilai GMD dilakukan dengan uji statistik. Berdasarkan Tabel 1 nilai signifikan yang diperoleh yaitu $1,1 \times 10^{-17}$. Nilai ini lebih kecil dari 0,05 sehingga perlakuan lama pengukusan memberikan pengaruh terhadap nilai GMD yang diperoleh.

Berdasarkan uji Duncan setelah perlakuan setelah dikukus 30 menit memiliki nilai GMD yang berbeda dengan perlakuan setelah dikukus 20 
menit dan tanpa perlakuan atau kontrol. Perlakuan setelah dikukus juga memiliki nilai GMD yang berbeda dengan perlakuan setelah dikukus 30 menit dan kontrol. Perlakuan kontrol juga memiliki nilai GMD yang berbeda dengan perlakuan setelah dikukus 20 menit dan perlakuan setelah dikukus 30 menit.

\section{Pengaruh Lama Pengukusan terhadap} Sphericity

Pengaruh lama pengukusan terhadap sphericity dapat dilihat pada Gambar 4. Perbedaan nilai sphericity dipengaruhi oleh perlakuan pada gabah.

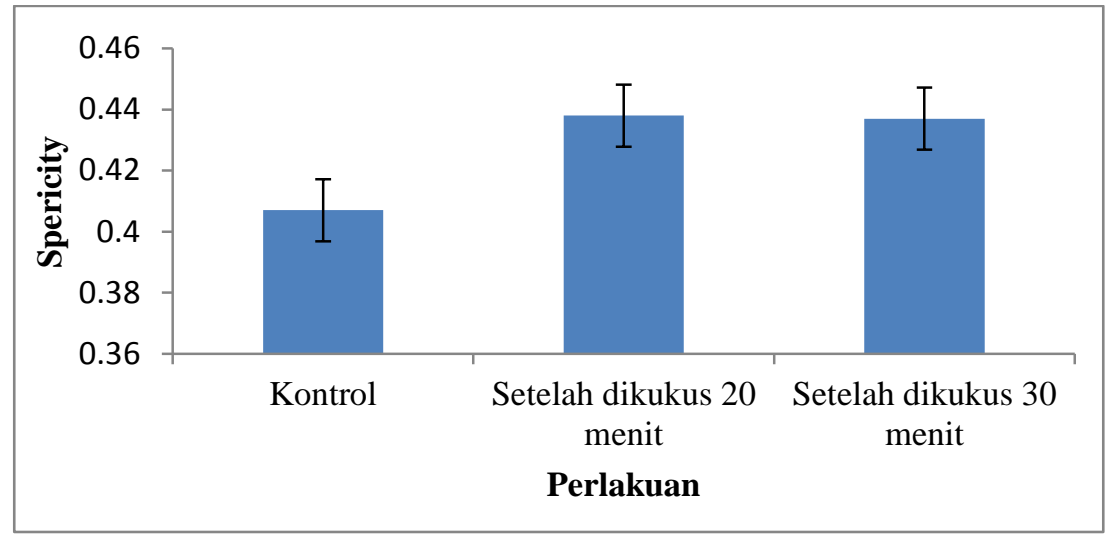

Gambar 4. Grafik Rata-rata Sphericity Gabah

Pada Gambar 4 terlihat grafik ratarata sphericity pada gabah, nilai terbesar sphericity yang diperoleh adalah pada perlakuan setelah dikukus 20 menit dengan nilai 0,438 sedangkan sphericity terkecil diperoleh pada perlakuan kontrol yaitu 0,407. Pada penelitian ini, lama pengukusan yang dapat meningkatkan kadar air tidak memberikan pengaruh terhadap nilai sphericity yang diperoleh. Analisa ANOVA untuk sphericity gabah dapat dilihat pada Tabel 2.

Tabel 2. Analisa ANOVA Sphericity Gabah

\begin{tabular}{cccccc}
\hline $\begin{array}{c}\text { Sumber } \\
\text { Keragaman }\end{array}$ & $\begin{array}{c}\text { Jumlah } \\
\text { Kuadrat }\end{array}$ & $\begin{array}{c}\text { Derajat } \\
\text { bebas }\end{array}$ & $\begin{array}{c}\text { Kuadrat } \\
\text { Tengah }\end{array}$ & F & Sig. \\
\hline Perlakuan & 0,062 & 2 & 0,031 & 108,080 & 0,000 \\
Galat & 0,085 & 297 & 0,000 & & \\
Total & 0,147 & 299 & & & \\
\hline
\end{tabular}

Perlakuan : Kontrol, Setelah dikukus 20 menit, Setelah dikuksu 30 menit

Analisa nilai sphericity gabah dilakukan dengan uji statistik. Nilai signifikan yang diperoleh yaitu 0,00 dimana nilai ini lebih kecil dari 0,05 sehingga perlakuan pada gabah memberikan pengaruh terhadap nilai sphericity gabah.

Berdasarkan analisa sphericity gabah maka dilanjutkan dengan uji
Duncan yang menjelaskan nilai rata-rata sphericity terhadap perlakuan pada gabah. Perlakuan kontrol memiliki nilai sphericity yang berbeda dengan perlakuan setelah dikukus 20 menit dan nilai sphericity setelah dikukus 30 sama dengan perlakuan setelah dikukus 20 menit. 
Pengaruh Lama Pengukusan terhadap Bulk density

Nilai bulk density diperoleh dari perbandingan massa dengan volume yang di tempatinya. Hubungan lama pengukusan terhadap bulk density dapat dilihat pada Gambar 5.

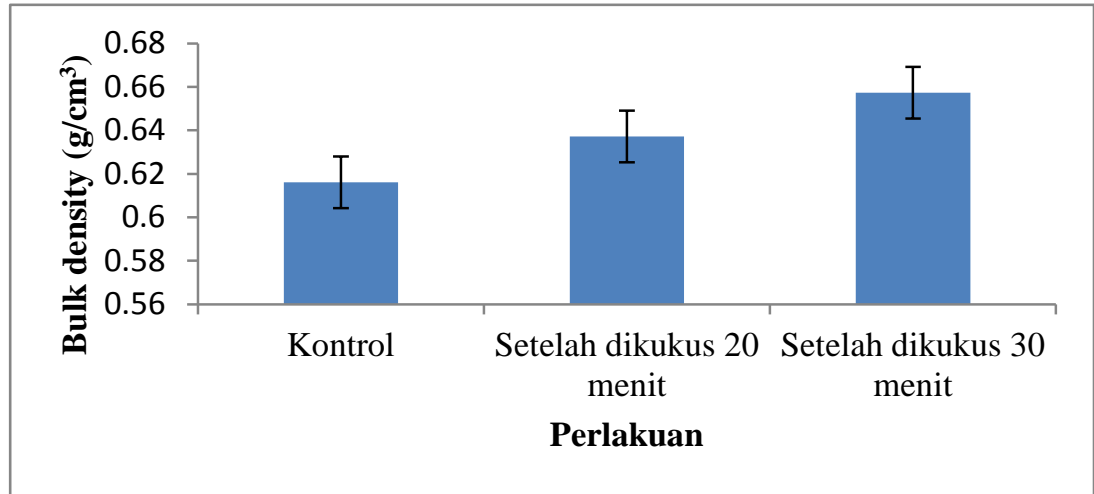

Gambar 5. Grafik Rata-rata Bulk Density Gabah

Berdasarkan Gambar 5 mengenai grafik rata-rata bulk density beras diperoleh nilai bulk density tertinggi pada perlakuan setelah pengukusan 30 menit yaitu $0,65731 \mathrm{~g} / \mathrm{cm}^{3}$, kemudian untuk nilai bulk density terendah yaitu pada gabah tanpa perlakuan atau kontrol dimana nilai bulk density adalah $0,61617 \mathrm{~g} / \mathrm{cm}^{3}$. Perbedaan nilai densitas yang diperoleh dipengaruhi oleh faktor tingginya kadar air yang terdapat di dalam butir gabah sehingga mempengaruhi volume gabah karena ukuran gabah pratanak yang lebih besar dibandingkan dengan gabah kontrol sehingga masih terdapat ruang ketika dimasukkan ke dalam gelas ukur. Selain itu, proses pengukusan juga mempengaruhi nilai bulk density pada gabah karena tahapan pengukusan dapat menambah massa dari gabah akibat uap panas yang dihasilkan ketika proses pengukusan. Sagita (2017) juga melakukan penelitian sifat fisik beberapa varietas gabah dan beras di Sumatera Barat juga memperoleh hasil pengaruh kadar air terhadap nilai bulk density dimana jika semakin rendah massa gabah, maka nilai bulk density semakin rendah. Analisa ANOVA bulk density gabah dapat dilihat pada Tabel 3.

Tabel 3. Analisa ANOVA Bulk density Gabah

\begin{tabular}{cccccc}
\hline $\begin{array}{c}\text { Sumber } \\
\text { Keragaman }\end{array}$ & $\begin{array}{c}\text { Jumlah } \\
\text { Kuadrat }\end{array}$ & $\begin{array}{c}\text { Derajat } \\
\text { Bebas }\end{array}$ & $\begin{array}{c}\text { Kuadrat } \\
\text { Tengah }\end{array}$ & F & Sig. \\
\hline Perlakuan & 0,002 & 2 & 0,001 & 187,144 & $3,9 \times 10^{-6}$ \\
Galat & 0,000 & 6 & 0,000 & & \\
Total & 0,003 & 8 & & & \\
\hline
\end{tabular}

Perlakuan : kontrol, Setelah dikukus 20 menit, Setelah dikukus 30 menit

Berdasarkan Tabel 3 terlihat uji statistik pengaruh perlakuan terhadap nilai bulk density. Nilai signifikasi yang diperoleh yaitu $3,9 \times 10^{-6}$ dimana nilai ini lebih kecil dari 0,05. Jika nilai signifikasi yang diperoleh lebih kecil dari 0,05 maka perlakuan memberikan pengaruh terhadap parameter yang 
diukur dan perlakuan setelah dikukus 20 menit dan dikukus 30 menit berpengaruh terhadap bulk density gabah yang diperoleh.

Setelah dilakukan analisis terhadap nilai bulk density pada gabah dilanjutkan dengan uji Duncan dimana diperoleh nilai bulk density yang berbeda-beda terhadap seluruh perlakuan. Nilai yang berbeda-beda ini dipengaruhi oleh perlakuan pada gabah. Nilai rata-rata bulk density terhadap perlakuan gabah setelah dikukus 20 menit, perlakuan setelah dikukus 30 menit dan kontrol.
Perlakuan kontrol memiliki nilai ratarata bulk density yang berbeda dengan perlakuan setelah dikukus 20 menit dan setelah dikukus 30 menit. Perlakuan setelah dikukus 30 menit berbeda dengan perlakuan kontrol dan perlakuan setelah dikukus 20 menit.

\section{Pengaruh Lama Pengukusan terhadap Massa 1000 biji Gabah}

Hubungan lama pengukusan terhadap massa 1000 biji dapat dilihat pada Gambar 6.

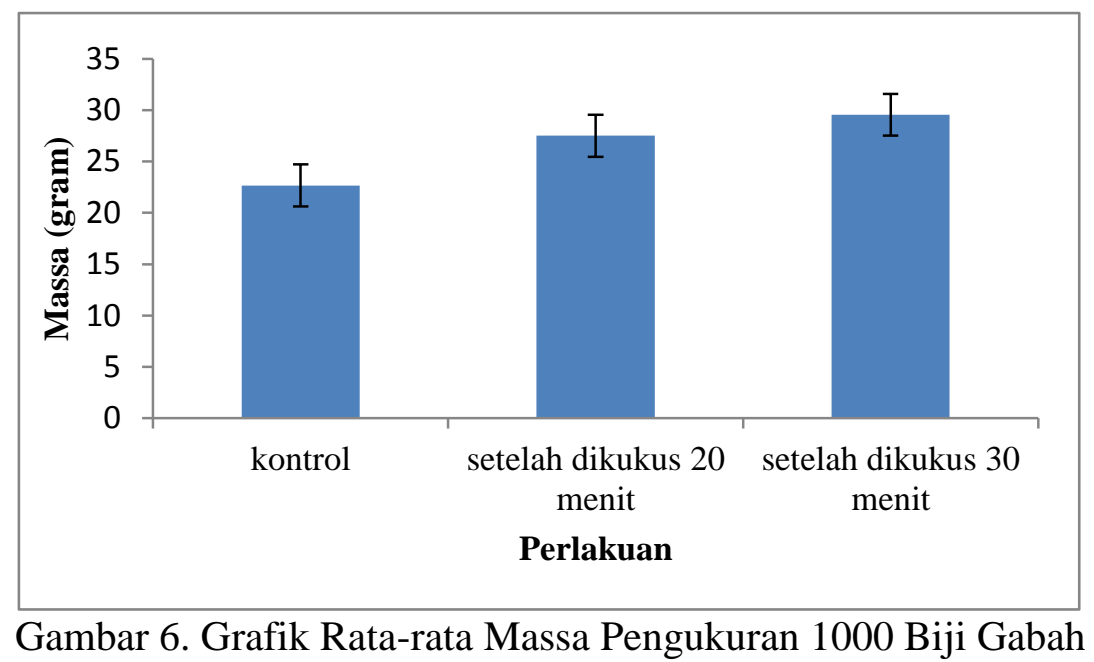

Berdasarkan Gambar 6 terlihat grafik rata-rata massa pengukuran 1000 biji gabah terhadap perlakuan setelah dikukus 20 menit, setelah dikukus 30 menit dan perlakuan kontrol. Massa tertinggi terdapat pada perlakuan setelah dikukus 30 menit yaitu 29,546 gram sedangkan massa terendah yaitu 22,668 gram pada gabah tanpa perlakuan atau kontrol. Perlakuan yang dilakukan terhadap gabah menjadi salah satu faktor yang mempengaruhi nilai massa yang diperoleh tidak sama. Selain itu, gabah yang telah direndam dan dikukus memiliki nilai kadar air yang lebih tinggi dibandingkan dengan gabah tanpa perlakuan sehingga mempengaruhi massa gabah tersebut. Penelitian yang dilakukan Sagita (2017) juga mendapatkan hasil yang serupa bahwa massa 1000 biji gabah akan meningkat seiring terjadinya peningkatan kadar air pada gabah. Semakin tinggi kadar air pada gabah maka massanya juga akan semakin besar. Analisa massa untuk 1000 biji gabah dapat dilihat pada Tabel 4. 
Tabel 4. Analisa ANOVA Massa 1000 biji Gabah

\begin{tabular}{cccccc}
\hline $\begin{array}{c}\text { Sumber } \\
\text { Keragaman }\end{array}$ & $\begin{array}{c}\text { Jumlah } \\
\text { Kuadrat }\end{array}$ & $\begin{array}{c}\text { Derajat } \\
\text { Bebas }\end{array}$ & $\begin{array}{c}\text { Kuadrat } \\
\text { Tengah }\end{array}$ & F & Sig. \\
\hline Perlakuan & 74,408 & 2 & 37,204 & 166,130 & $5,58 \times 10-6$ \\
Galat & 1,344 & 6 & 0,224 & & \\
Total & 75,752 & 8 & & & \\
\hline
\end{tabular}

Perlakuan : Kontrol : Setelah dikukus 20 menit : Setelah dikukus 30 menit

Berdasarkan Tabel 4 diperoleh nilai signifikasi terhadap perlakuan lama pengukusan 20 menit dan 30 menit dengan massa 1000 biji. Jika nilai signifikasi yang diperoleh lebih kecil dari 0,05 maka perlakuan memberikan pengaruh terhadap massa 1000 biji. Nilai signifikasi yaitu $5,58 \times 10^{-6}$ yang lebih kecil dari 0,05 sehingga lama pengukusan memberikan pengaruh terhadap massa 1000 biji.

Berdasarkan analisa massa 1000 biji gabah maka dilakukan uji Duncan, terlihat perlakuan lama pengukusan memberikan pengaruh terhadap massa 1000 biji gabah. Perlakuan kontrol memiliki massa 1000 biji yang berbeda dengan perlakuan pengukusan setelah dikukus 20 menit dan setelah dikukus 30 menit. Massa 1000 biji pada perlakuan setelah dikukus 20 menit juga berbeda dengan perlakuan setelah dikukus 30 menit dan perlakuan kontrol, dan begitu juga pada perlakuan setelah dikukus 30 menit memiliki nilai massa 1000 biji yang berbeda dengan perlakuan setelah dikukus 20 menit dan perlakuan kontrol.

\section{Pengaruh Lama Pengukusan terhadap Kadar Air}

Kadar air yang diamati adalah persentase kandungan air suatu bahan yang dapat dinyatakan berdasarkan basis basah. Hubungan kadar air dengan lama pengukusan pada gabah dan beras dapat dilihat pada Gambar 7.

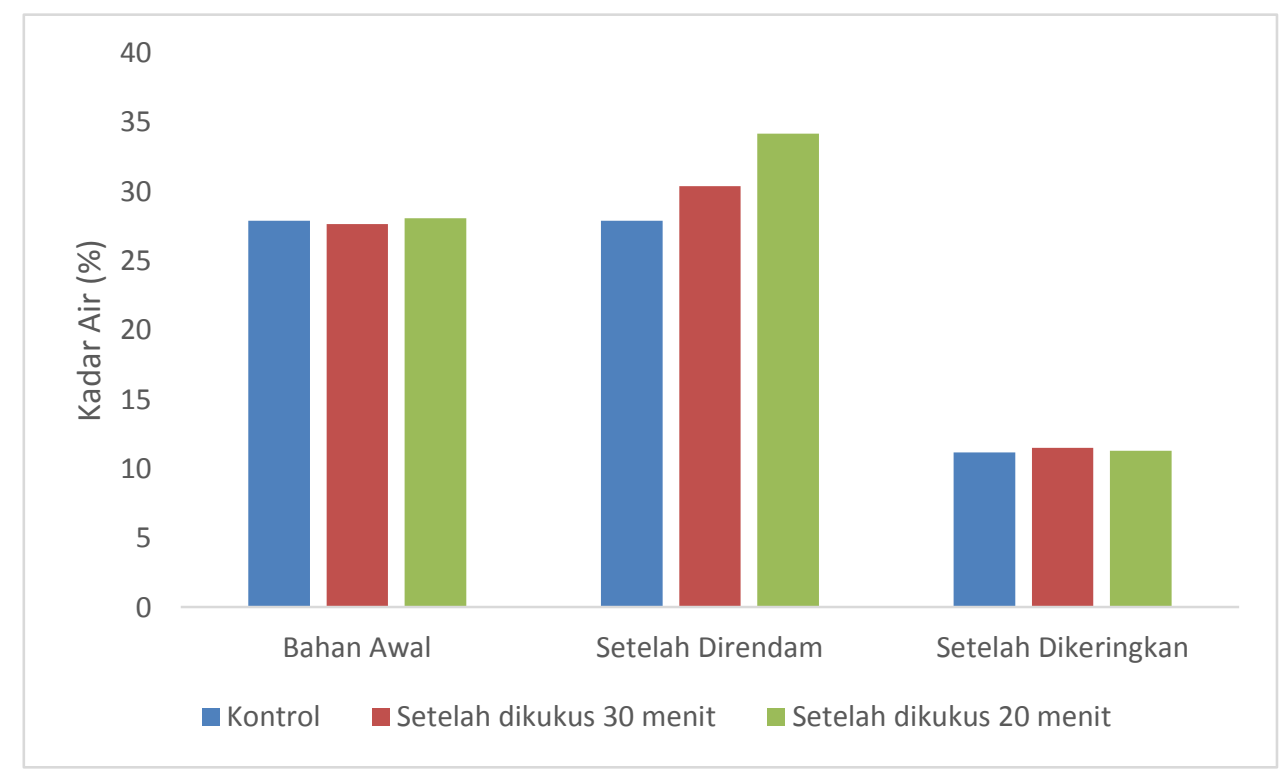

Gambar 7. Distribusi Kadar Air Awal 
Pada Gambar 7 terlihat grafik kadar air pada gabah awal setelah panen, gabah setelah direndam dan beras. Pada grafik pengukuran kadar air awal gabah setelah panen yaitu $27,845 \%$. Kemudian gabah diberikan perlakuan perendaman selama 4 jam dengan suhu $60^{\circ} \mathrm{C}$ disetiap perlakuan. Pada perlakuan setelah dikukus 20 menit persentase kadar air yang diperoleh adalah 30,359\% dan gabah setelah dikukus 30 menit adalah $34,145 \%$. Peningkatan kadar air ini disebabkan karena gabah menyerap banyak air ketika tahapan perendaman sehingga persentase kadar air menjadi meningkat. Kemudian tahapan pengeringan dilakukan hingga diperoleh kadar air rata-rata $14 \%$ seperti pada Gambar 7. Tahapan penyosohan mempengaruhi persentase kadar air beras karena persentase yang diperoleh pada perlakuan setelah dikukus 20 menit yaitu $13,540 \%$ dan perlakuan setelah dikukus 30 menit yaitu 13,358\% yang dipengaruhi oleh tahapan penggilingan. Pengaruh kadar air terhadap mutu beras pada varietas Siam Sabah juga memperoleh hasil kadar air yang berkisar $14,20 \%$ yang menghasilkan mutu beras yang baik. Analisa ANOVA kadar air dapat dilihat pada Tabel 5.

Tabel 5. Analisa ANOVA Kadar Air

\begin{tabular}{cccccc}
\hline $\begin{array}{c}\text { Sumber } \\
\text { Keragaman }\end{array}$ & $\begin{array}{c}\text { Jumlah } \\
\text { kuadrat }\end{array}$ & $\begin{array}{c}\text { Derajat } \\
\text { bebas }\end{array}$ & $\begin{array}{c}\text { Kuadrat } \\
\text { Tengah }\end{array}$ & F & Sig. \\
\hline Perlakuan & 0,136 & 2 & 0,068 & 1,608 & 0,276 \\
Galat & 0,253 & 6 & 0,042 & & \\
Total & 0,389 & 8 & & & \\
\hline
\end{tabular}

Perlakuan: Kontrol, Setelah dikukus 20 menit, Setelah dikukus 30 menit

Berdasarkan Tabel 5, terlihat analisa ANOVA kadar air beras dengan uji statistik dimana diperoleh nilai signifikasi 0,276. Nilai signifkasi dapat dikatakan memberikan pengaruh terhadap perlakuan apabila nilai signifikasi lebih kecil dari 0,05. Nilai signifikasi kadar air yang diperoleh lebih besar dari 0,05 sehingga perlakuan tidak memberikan pengaruh terhadap kadar air beras.

Berdasarkan uji statistik maka dilakukan uji lanjut Duncan. Perlakuan setelah dikukus 30 menit memiliki nilai kadar air yang tidak jauh berbeda dengan perlakuan setelah dikukus 20 menit dan kontrol. Perlakuan setelah dikukus 20 menit memiliki nilai kadar air yang tidak jauh berbeda dengan kontrol dan perlakuan setelah dikukus 30 menit.

\section{Pengaruh Lama Pengukusan terhadap Rendemen}

Rendemen merupakan perbandingan beras giling yang dapat diperoleh dari sejumlah gabah. Hubungan lama pengukusan terhadap rendemen dapat dilihat pada Gambar 8. 


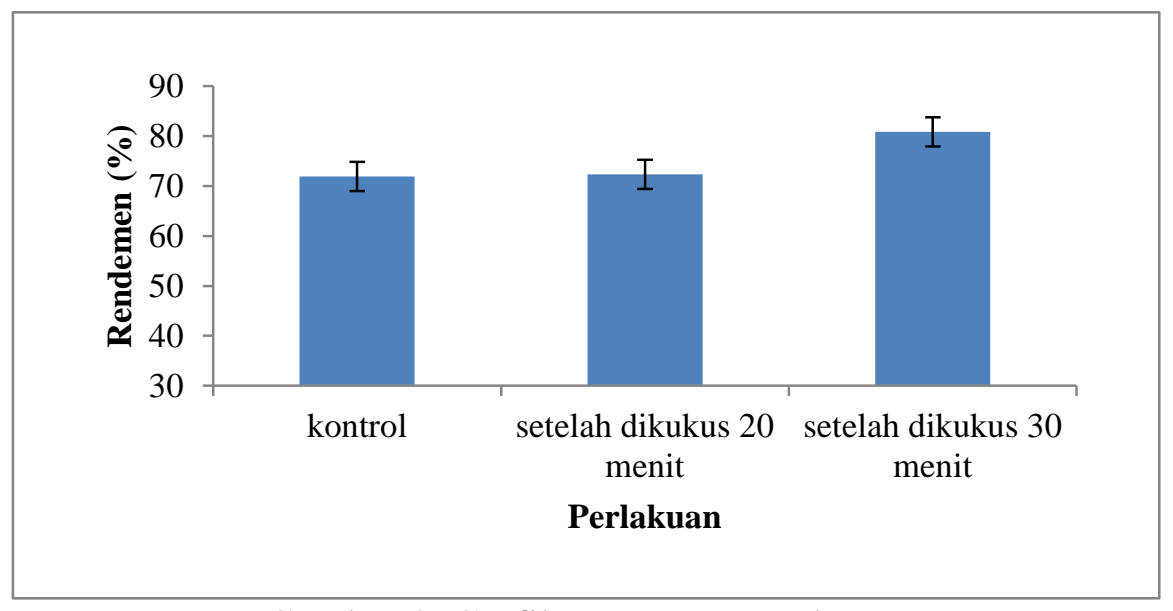

Gambar 8. Grafik Rata-rata Rendemen

Berdasarkan Gambar 8 terlihat grafik rata-rata rendemen beras terhadap perlakuan setelah dikukus 30 menit, perlakuan setelah dikukus 20 menit dan tanpa perlakuan. Persentase rendemen beras tanpa perlakuan yaitu $71,938 \%$ sedangkan persentase rendemen perlakuan setelah dikukus 20 menit adalah $72,305 \%$, dan persentase rendemen pada perlakuan seelah dikukus 30 menit adalah 80,860\%. Peningkatan rendemen ini dipengaruhi oleh proses pengukusan yang membuat ikatan selsel beras menjadi lebih kompak dan kuat sehingga pada proses penggilingan lebih tahan terhadap gesekan saat pengupasan dan penyosohan (Akhyar, 2009).

Persentase rendemen giling juga dipengaruhi oleh persentase kadar air dimana kadar air yang optimal untuk penggilingan yaitu $13-15 \%$ sehingga apabila kadar air lebih rendah maka butiran gabah akan mudah menjadi patah ketika proses penggilingan dan akan menurunkan persentase rendemen. Persentase rendemen giling pada perlakuan setelah dikukus 30 menit lebih besar dibandingkan dengan perlakuan setelah dikukus 20 menit dan tanpa perlakuan atau kontrol karena proses perendaman dan pengukusan yang dapat meningkatkan nilai kadar air pada gabah. Hasil penelitian ini sejalan dengan penelitian yang dilakukan oleh Putri et al., (2015) bahwa persentase nilai rendemen dipengaruhi oleh kadar air pada gabah, semakin rendah kadar air, maka rendemen akan semakin rendah karena butir patah akan semakin banyak. Analisa ANOVA untuk rendemen beras dapat dilihat pada Tabel 6 .

Tabel 6. Analisa ANOVA Rendemen

\begin{tabular}{cccccc}
\hline $\begin{array}{c}\text { Sumber } \\
\text { Keragaman }\end{array}$ & $\begin{array}{c}\text { Jumlah } \\
\text { kuadrat }\end{array}$ & $\begin{array}{c}\text { Derajat } \\
\text { bebas }\end{array}$ & $\begin{array}{c}\text { Kuadrat } \\
\text { Tengah }\end{array}$ & F & Sig. \\
\hline Perlakuan & 96,608 & 2 & 15,355 & 66,300 & 0,004 \\
Galat & 18,875 & 6 & 3,146 & & \\
Total & 115,483 & 8 & & & \\
\hline
\end{tabular}

Perlakuan :Kontrol, Setelah dikukus 20 menit, Setelah dikukus 30 menit 
Berdasarakan Tabel 6 terlihat analisa ANOVA rendemen beras dengan uji statistik, dimana nilai signifikasi yang diperoleh yaitu 0,004. Nilai yang diperoleh memberikan pengaruh terhadap perlakuan apabila nilai signifikasi lebih kecil dari 0,05. Pada Tabel 6 nilai signifikasi yang diperoleh lebih kecil dari 0,05 sehingga perlakuan berpengaruh terhadap rendemen.

Berdasarkan analisa rendemen beras maka dilakukan uji lanjut Duncan, terlihat bahwa perlakuan setelah dikukus 30 menit berbeda dengan perlakuan setelah dikukus 20 menit dan kontrol sedangkan perlakuan 20 menit memiliki rendemen yang sama dengan tanpa perlakuan atau kontrol dan berbeda dengan perlakuan setelah dikukus 30 menit.

\section{Pengaruh Lama Pengukusan Terhadap Mutu Fisik}

Mutu giling pada beras pratanak mengacu berdasarkan SNI 01-6128:2008 yaitu hasil utama yang diperoleh dari proses penggilingan gabah. Pengamatan mutu fisik ini meliputi butir kepala, butir patah, butir menir, butir kuning, dan butir merah. Persentase butir kepala pada perlakuan kontrol yaitu 64,256\% dilanjutkan pada perlakuan setelah dikukus 20 menit dan 30 menit yaitu $40,006 \%$ dan 45,662\%. Hal ini dipengaruhi akibat perlakuan pada beras pratanak sehingga kandungan air pada beras pratanak lebih tinggi sehingga mempengaruhi mutu fisik pada beras.

Tabel 7 . Klasifikasi Mutu Fisik Beras Pratanak

\begin{tabular}{ccccc}
\hline & & \multicolumn{3}{c}{ Perlakuan } \\
\cline { 3 - 5 } No & Klasifikasi & Kontrol $(\%)$ & $\begin{array}{c}\text { Setelah dikukus } \\
\text { 20 menit }(\%)\end{array}$ & $\begin{array}{c}\text { Setelah dikukus } \\
\text { 30 menit }(\%)\end{array}$ \\
\hline 1. & Butir Kepala & 64,256 & 40,006 & 45,662 \\
2. & Butir Patah & 22,679 & 21,804 & 16,176 \\
3. & Butir Menir & 10,523 & 28,505 & 33,328 \\
4. & Butir Kuning & 0,104 & 0,125 & 0,054 \\
5. & Butir Merah & 0,009 & 0,196 & 0,246 \\
\hline
\end{tabular}

Berdasarkan hasil pada Tabel 7 dapat terlihat bahwa lama pengukusan berpengaruh terhadap mutu beras yang diperoleh. Butir kepala berdasarakan SNI 01-6128:2008 adalah butir beras dengan ukuran lebih besar atau sama dengan 0,8 bagian dari butir beras utuh. Persentase untuk butir kepala pada perlakuan kontrol sebesar 64,256\%, kemudian untuk perlakuan setelah dikukus 20 menit dan setelah dikukus 30 menit adalah 40,006\% dan $45,662 \%$.Hasil persentase beras kepala pada beras pratanak lebih rendah dibandingkan dengan persentase beras kontrol karena dipengaruhi oleh proses perendaman sehingga gelatinisasi pati belum sempurna sehingga menyebabkan beras menjadi rapuh dan mudah patah ketika dilakukan penggilingin.

Persentase beras patah pada perlakuan kontrol berdasarkan Tabel 7 yaitu $22,679 \%$ dan perlakuan setelah dikukus 20 menit dan setelah dikukus 30 menit $21,804 \%$ dan 16,176\%. Apabila dibandingkan antara persentase butir patah beras pratanak pada perlakuan setelah dikukus 20 menit dan setelah dikukus 30 menit, maka persentase terbesar yaitu pada perlakuan setelah dikukus 20 menit dibandingkan dengan perlakuan setelah dikukus 30 menit. 
Penelitian yang dilakukan Fadhallah et al., (2016) juga memperoleh hasil persentase butir patah lebih besar pada perlakuan dikukus selama 20 menit yaitu 20-58\%. Butir menir menurut SNI 016128:2008 yaitu beras dengan ukuran lebih kecil dari 0,2 bagian beras utuh. Persentase beras menir pada perlakuan kontrol yaitu 10,523\% dan persentase beras menir pada perlakuan setelah dikukus 20 menit dan setelah dikukus 30 menit berturut-turut yaitu $28,505 \%$ dan $33.328 \%$. Penelitian juga telah dilakukan oleh Akhyar (2009) yang memperoleh persentase beras menir dari beras pratanak antara 2,34 - 23,11\% karena varietas berpengaruh nyata terhadap beras pratanak.

\section{Kadar Pati Beras Pratanak}

Kadar pati dilakukan terhadap beras dengan beberapa perlakuan yaitu perlakuan setelah dikukus 20 menit, setelah dikukus 30 menit dan kontrol. Kadar pati merupakan salah satu kriteria mutu untuk tepung. Persentase kadar pati dapat dilihat pada Gambar 9.

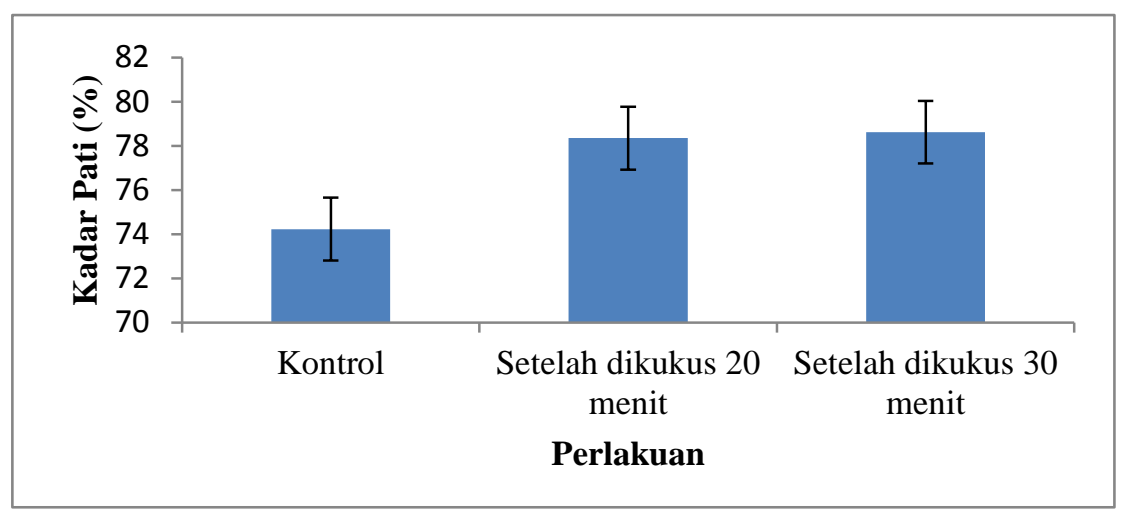

Gambar 9. Grafik Rata-rata Kadar Pati Beras Pratanak

Berdasarkan pada Gambar 9 mengenai kadar pati beras pratanak nilai terbesar yaitu $78,614 \%$ pada perlakuan setelah dikukus 30 menit kemudian dilanjutkan dengan perlakuan setelah dikukus 20 menit yaitu $78,342 \%$ dan perlakuan kontrol yaitu $74,227 \%$. Beras yang diberi perlakuan pengukusan cenderung memiliki kadar pati yang lebih tinggi dibandingkan dengan tanpa perlakuan. Penelitian yang telah dilakukan oleh Apriliani (2016) juga memperoleh peningkatan kadar pati pada beras pratanak varietas Inpari 24 sebesar $73,48 \%$ hingga $79,76 \%$. Hasil analisa ANOVA kadar pati beras pratanak dapat dilihat pada Tabel 8 .

Tabel 8. Analisa ANOVA Kadar Pati Beras Pratanak

\begin{tabular}{cccccc}
\hline $\begin{array}{c}\text { Sumber } \\
\text { Keragaman }\end{array}$ & $\begin{array}{c}\text { Jumlah } \\
\text { kuadrat }\end{array}$ & $\begin{array}{c}\text { Derajat } \\
\text { bebas }\end{array}$ & $\begin{array}{c}\text { Kuadrat } \\
\text { Tengah }\end{array}$ & F & Sig. \\
\hline Perlakuan & 24,169 & 2 & 12,084 & 97,272 & 0,002 \\
Galat & 0,373 & 3 & 0,124 & & \\
Total & 24,541 & 5 & & & \\
\hline
\end{tabular}

Perlakuan :Kontrol, Setelah dikukus 20 menit, Setelah dikukus 30 menit 
Berdasarkan Tabel 8 terlihat analisa ANOVA kadar pati beras terhadap beberapa perlakuan. Perlakuan dapat dikatakan berpengaruh terhadap kadar pati jika nilai signifikasi lebih kecil dari 0,05 sedangkan apabila nilai signifikasi yang diperoleh lebih besar dari 0,05 maka perlakuan tidak berpengaruh terhadap kadar pati. Nilai signifikasi yang diperoleh berdasarakan Tabel 7 yaitu 0,002 sehingga perlakuan memberikan pengaruh terhadap kadar pati beras.

Berdasarkan uji Duncan, untuk perlakuan setelah dikukus 20 menit memiliki nilai kadar pati yang berbeda dengan perlakuan kontrol, perlakuan setelah dikukus 30 menit juga memiliki nilai kadar pati berbeda dengan perlakuan kontrol dan sama dengan perlakuan setelah dikukus 20 menit.

\section{Kadar Glukosa Beras Pratanak}

Analisa kadar glukosa ini dilakukan untuk mengetahui banyaknya kandungan gula yang terdapat pada beras yang telah diberi perlakuan. Persentase kadar glukosa dengan perlakuan yang diberikan pada beras dapat dilihat pada Gambar 10.

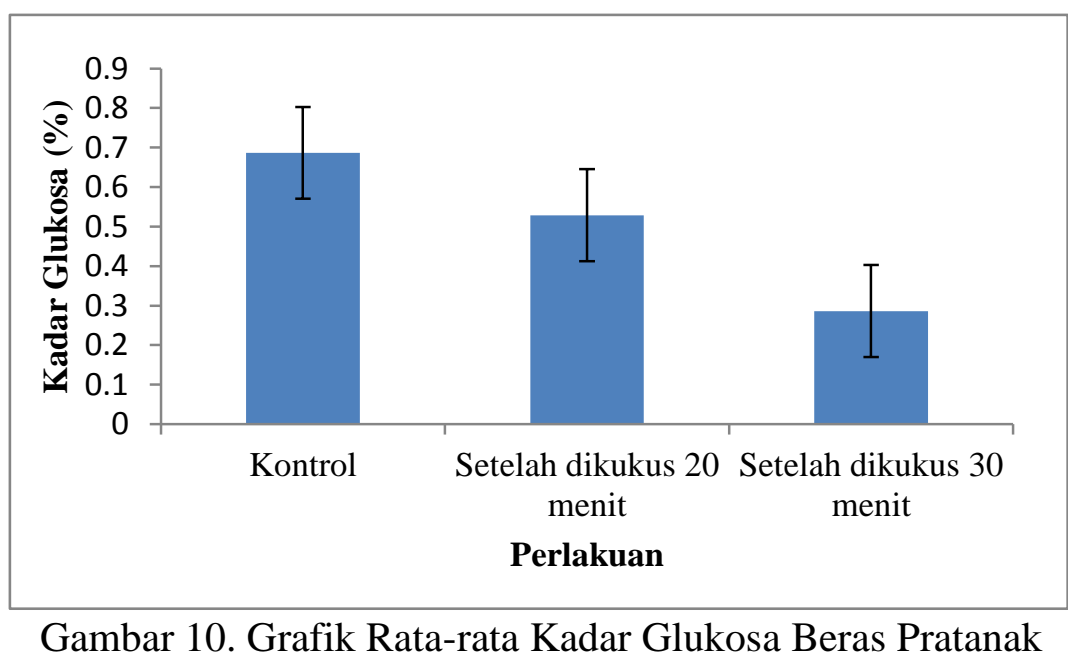

Berdasarkan Gambar 10 persentase kadar gula tertinggi pada beras tanpa perlakuan yaitu $0,6865 \%$ dan perlakuan setelah dikukus 20 menit $0,5288 \%$ serta perlakuan setelah dikukus 30 menit $0,28625 \%$. Perbedaan persentase kadar glukosa ini disebabkan karena perlakuan pengukusan sehingga mempengaruhi kadar air pada beras dan berpengaruh pada kadar glukosa beras. Penelitian yang telah dilakukan oleh Apriliani
(2016) juga memperoleh kadar glukosa beras pratanak pada varietas Inpari 24 yaitu 0,09-2,18\%. Persentase kadar glukosa sangat berhubungan dengan indeks glikemik sehingga varietas juga mempengaruhi kandungan glukosa karena setiap jenis padi memiliki nilai indeks glikemik yang berbeda-beda. Hasil analisa kadar glukosa beras pratanak dapat dilihat pada Tabel 9. 
Tabel 9. Analisa ANOVA Kadar Glukosa

\begin{tabular}{cccccc}
\hline $\begin{array}{c}\text { Sumber } \\
\text { Keragaman }\end{array}$ & $\begin{array}{c}\text { Jumlah } \\
\text { Kuadrat }\end{array}$ & $\begin{array}{c}\text { Derajat } \\
\text { Bebas }\end{array}$ & $\begin{array}{c}\text { Kuadrat } \\
\text { Tengah }\end{array}$ & F & Sig. \\
\hline Perlakuan & 0,163 & 2 & 0,081 & 14,832 & 0,028 \\
Galat & 0,016 & 3 & 0,005 & & \\
Total & 0,179 & 5 & & & \\
\hline
\end{tabular}

Perlakuan : Kontrol, Setelah dikukus 20 menit, Setelah dikukus 30 menit

Berdasarkan Tabel 9 menunjukkan kadar glukosa pada perlakuan beras kontrol, setelah dikukus 20 menit dan setelah dikukus 30 menit. Perlakuan dapat memberikan pengaruh terhadap kadar glukosa apabila nilai signifikasi yang diperoleh lebih kecil dari 0,05. Pada Tabel 22 nilai signifikasi yang diperoleh adalah 0,028 sehingga perlakuan memberikan pengaruh terhadap kadar glukosa beras.

Berdasarkan analisis uji statistik, kemudian dilanjutkan dengan uji Duncan. Pada perlakuan setelah dikukus 30 menit memiliki nilai kadar glukosa yang berbeda dengan perlakuan setelah dikukus 20 menit dan kontrol. Nilai kadar glukosa pada perlakuan kontrol berbeda dengan setelah dikukus 30 menit dan memiliki kadar glukosa yang sama dengan perlakuan kontrol.

\section{KESIMPULAN}

1. Lama pengukusan memberikan pengaruh terhadap sifat fisik gabah dengan nilai GMD sebesar 3,562; nilai sphericity sebesar 0,438 ; nilai bulk density sebesar $0,656 \mathrm{~g} / \mathrm{cm}^{3}$ dan nilai massa 1000 biji sebesar 29,546 g.

2. Pengolahan beras pratanak dapat meningkatkan rendemen. Perlakuan setelah dikukus 30 menit adalah $80,860 \%$; perlakuan setelah 20 menit adalah $72,305 \%$; dan tanpa perlakuan yaitu $71,983 \%$
3. Persentase kadar air dapat mempengaruhi mutu fisik beras yang diperoleh dengan lama pengukusan selama 30 menit memiliki kadar air beras 13,358\% dengan persentase butir kepala $45,662 \%$ butir patah $16,176 \%$ butir menir 33,328\%, butir kuning $0,054 \%$. Sedangkan lama pengukusan selama 20 menit memiliki nilai kadar air beras $13,656 \%$ dengan persentase butir kepala 40,006\% butir patah $21,804 \%$, butir menir $28,505 \%$ dan butir kuning $0,125 \%$.

4. Pengujian organoleptik terhadap rasa, aroma dan warna yang dilakukan terhadap responden memperoleh hasilsebagian besar lebih menyukai beras setelah pengukusan 20 menit.

5. Perlakuan pengukusan selama 20 menit dan 30 menit dapat meningkatkan kadar pati sebesar $78,619 \%$ dan menurunkan kadar glukosa pada beras berkisar 0,2863$0,5288 \%$.

\section{DAFTAR PUSTAKA}

Akhyar. 2009. Pengaruh Proses Pratanak Terhadap Mutu Gizi dan Indeks Glikemik Berbagai Varietas Beras Indonesia [Thesis]. Bogor. Institut Pertanian Bogor

Alegria et al., 2001. Physical and Thermal Properties of Parachment 
Coffee Bean. Transactions of the ASAE vol 44(6) 1721-1726. American Society of Agricultur Engineers

Apriliani, Sarah Anita. 2016. Karakteristik Beras Pratanak yang Terbuat dari Gabah Kering Panen dan Gabah Kering Giling [Skripsi]. Bogor. Institut Pertanain Bogor

Badan Standarisasi Nasional. 2008. Persyaratan Mutu Beras Giling. SNI 01-61282008.http://kaltim.litbang.pertania n.go.id/ind/index.php?option\%3Dc om_content\%26view\%3Darticle\% 26id\%3D715:standar-mutu-gabahdan-beras-

giling\%26catid\%3D66:padi\%26Ite mid\%3D59\&hl=en-ID (diakses 2 September 2017)

Badan Pusat Statistik. 2017. Konsumsi Beras di Indonesia. https://www.bps.go.id/statictable/2 014/09/08/950/rata-rata-konsumsiper-kapita-seminggu-beberapamacam-

Fadhallah, Esa Ghanim. 2016. Kajian Proses Perendaman dan Pengukusan untuk Meningkatkan Mutu Beras Pratanak pada Beberapa Varietas Gabah [Thesis]. Bogor :Institut Pertanian Bogor.

Haryadi. 2006. Teknologi Pengolahan Beras. Yogyakarta :Gadjah Mada University Press

Hasbullah, Rokhani dan Pramita Riskia. 2013. Pengaruh Lama Perendaman Terhadap Mutu Beras Pratanak pada Padi Varietas IR 64. Bogor. Jurnal Keteknikan Pertanian Vol 27 No 1
Muchtadi dan Sugiyono. 1992. Teknologi Proses Pengolahan Pangan. Bogor : Institut Pertanian Bogor.

Putri, Renny Eka, et al. 2018. Influence of Moisture Content to the Physical Properties of Unhusk Rice Grain. Advanced Science Engineering Information Technology Vol. 8 No 3

Rimbawan, Siagian A. 2004. Indeks Glikemik Pangan. Jakarta: Penebar Swadaya

Sagita, Widyana. 2017. Studi Sifat Fisik Beberapa Varietas Gabah dan Beras di Sumatera Barat [skripsi]. Padang. Universitas Andalas

Singh, R. K., Vishwakarma, R.K., Vishal, M.K., Singh, S.K. and Saharan, V.K. 2015. Moisture Dependent Physical Properties of Nigella Seed. African Journal of Agricultural Research.

Spetriani. 2011. Kajian Teknologi Proses Pengolahan Beras Pratanak (Parboiling Rice) pada Gabah Varietas Situ Bagendit [Skripsi]. Bogor: Institut Pertanian Bogor

Widowati, Sri. 2009. Penurunan Indeks Glikemik Berbagai Varietas Beras Melalui Proses Pratanak. Bogor: Jurnal Pascapanen Vol 6 (1) hal. 19.

Zareiforoush, H., Hosseinzadeh, B., Adabi, M.E., and Motavali, A. 2011. Moisture- Depent Physical Properties of Paddy Grains.Journal of American Science. 7:7. 